\title{
Emerging Markets Commerce: The Role of Country-of-Origin and Animosity in Purchase Intention
}

\author{
Nadia Jiménez ${ }^{1} \&$ Sonia San Martín ${ }^{2}$ \\ ${ }^{1}$ Coordinación Académica Región Altiplano, Universidad Autónoma de San Luis Potosí, México \\ ${ }^{2}$ Facultad de Ciencias Económicas y Epresariales, Universidad de Burgos, España \\ Correspondence: Nadia Huitzilin Jiménez Torres, Coordinación Académica Región Altiplano, Universidad \\ Autónoma de San Luis Potosí, Carr. Cedral Km. 5+6000 C.P. 78700, San Luis Potosí, México. E-mail: \\ nadia.jimenez@uaslp.mx
}

Received: May 3, 2012 Accepted: August 20, $2012 \quad$ Published: September 1, 2012

doi:10.5539/ijbm.v7n17p34 URL: http://dx.doi.org/10.5539/ijbm.v7n17p34

\begin{abstract}
At present, firms must face interrelated challenges in global marketing, such as the increased consumer market internationalization and the rapid growth of emerging markets economy. In this context, the purpose of this study is to differentiate between cognitive and affective components of the country-of-origin (reputation of firms from a country-of-origin and animosity) and frame them as antecedents of trust and purchase intention. The study supports the view that the reputation of firms from the country-of-origin helps to engender trust in international markets and indirectly impacts purchase intention. Also, this study analyses the mediation role that trust plays in the relationship between reputation of firms from the country-of-origin, consumer animosity and purchase intention.
\end{abstract}

Keywords: country-of-origin, trust, reputation, animosity, emerging markets

\section{Introduction}

Despite growing interest in understanding consumer attitudes and behaviors towards products from emerging markets, the research into country-of-origin (COO) affective and cognitive effects on purchase intention and trust in brands from emerging markets is scarcely (Sharma, 2011; Maher \& Carter 2011). This paper introduces a conceptual framework incorporating socio-psychological and marketing variables to recognize the motivations underlying consumer perceptions and behavior towards imported products. As recommended by previous research, studies are needed to understand consumer behaviour in emerging markets in an integral way that offers a conceptual perspective which is better aligned with the reality and explores country-of-origin (COO) effects (Amine \& Chao, 2005). In this sense, the existence and importance of the 'country-of-origin' effect has generated a multitude of studies and more than a little controversy over the past five decades (Roth \& Diamantopoulous, 2009). However, this is not surprising taking account of the fact that we are dealing with a complex and multidimensional phenomenon, with multiple roots and wide-ranging effects. One only needs to look at how the subject may be approached. Some authors explore product origin as one more of its defining attributes whilst others might consider it as a sign of quality. For others, product $\mathrm{COO}$ is a criterion to distinguish between what is internal (national) as opposed to what is external (foreign) to the group. Some researchers centre their attention on consumer feelings and attitudes towards the country itself (Shimp \& Sharma, 1987; Amine, 2008).

In order to understand the complexity of the phenomenon, Parameswaran \& Pisharodi (1994) and Roth \& Diamantopoulous (2009) stress the need to study product origin from a range of different perspectives, exploring the relevance of $\mathrm{COO}$ and the psycho-sociological construct in new social contexts in an effort to gauge whether consumer responses and buyer behavior are determined by consumption context and cultural variables. In this sense, the main contributions of this research lie in combining different analytical perspectives on the country-of-origin effect and using multidisciplinary concepts from marketing, psychology and sociology to enrich our understanding of consumer behavior in emerging markets. More particularly, its contributions to both theory and practice are as follows. 1) To test the $\mathrm{COO}$ reputation of firms from an emerging market capacity to generate trust in firms from this country, usually characterized by the scant amount of institutional-based trust 
placed in them by international markets. 2) To study if consumers from a transitional economy show animosity and how it affects their purchase intention and their trust in foreign firms from an emerging market. 3) To analyse the mediation role that trust plays in the relationship between reputation of firms from the country-of-origin, consumer animosity and purchase intention The structure of this paper is as follow: The second epigraph presents the key variables and the hypotheses. Later, the third epigraph sets out the research method and the results. Finally, the fourth epigraph presents the main conclusions, implications, limitations and future lines of research.

\section{Conceptual Framework}

\subsection{Components of COO Effect and Their Consequences}

When evaluating products of diverse origin, a complex situation involving asymmetric information, consumers can use the reputation of firms from the $\mathrm{COO}$ as a signal that will help them in their purchase decision-making process (Kang \& Yang, 2010; Roth \& Diamantopoulos, 2009; Shi, Wen \& Fan, 2012). Thus, when consumers experience difficulties in understanding all of the relevant information concerning the true attributes of the products prior to purchase, they can draw on reputation of COO firms to evaluate products from that country, understood as a signal that summarises the quality characteristics of the products of the firms from an emerging COO, as well as the behaviour of those firms (Fombrun \& Shanley, 1990; Kang \& Yang, 2010; Hamzaoui, Merunka \& Bartikowski, 2011). As with the reputation of COO firms, animosity also involves discrimination against products on the basis of their origin (Klein, Ettenson \& Morris., 1998; Hoffmann, Mai \& Smirnova., 2011) and expresses itself as an affective or (negative) emotional reaction towards products from a certain foreign country. Scholars stand out the interest in studying the animosity, because this variable has important implications for international commerce (Klein et al., 1998; Nijssen \& Douglas, 2004; Hoffmann et al., 2011) and due to its impact on individual purchasing behaviour towards foreign products (Hoffmann et al., 2011). We understand that consumer animosity is the antipathy toward a certain country, which negatively affects the intention to buy products imported from that country (Hoffmann et al., 2011; p. 236).

Regarding the consequences of $\mathrm{COO}$ reputation and animosity, a critical issue in Relationship Marketing Theory is the development of trust. However, as trust depends on the firm's country-of-origin, managers will need to employ different incentives to induce perceived firm reliability in international markets. Literature points out that firms which establish relational exchanges and develop trustworthiness gain competitive advantages, and achieve superior financial performances, as well as enhanced consumer satisfaction and loyalty (Kalwani \& Narayandas, 1995; Morgan \& Hunt, 1994). Trust involves consumer willingness to be vulnerable, and to believe that the chosen exchange partner (the firm) will act in the truster's (consumer's) interests and will behave responsibly and with integrity (Ganesan, 1994).

Trust depends on many factors such as shared values, communication strategies, opportunistic behaviour, cultural similarity, goal congruence, satisfaction, risk as well as product and firm attributes and institutional country's issues associated with social structures that guarantee transactions (Dahlstrom \& Nygaard, 1995; Singh \& Sirdeshmukh, 2000; Morgan \& Hunt, 1994). For instance, consumers associate firms from mature market economies with established international trade rules and with institutional elements emanating from legislation that ensure contractual obligations and reduce individuals' uncertainty (i.e., legal regulation, bureaucratic organizations and export quality controls). In emerging market economies, with no well-established institutional-based trust, firms need to provide other safeguard mechanisms to generate consumer trust and establish international exchanges (Dahlstrom \& Nygaard, 1995). Previous studies show that signals of quality (e.g., reputation, $\mathrm{COO}$ ) have more relevance and influence on relationship variables in countries with weak regulatory systems (Steenkamp \& Geyskens, 2006). Kang and Yang (2010) affirm that a powerful and positive $\mathrm{COO}$ brand provides a crucial competitive advantage and it is essential for emerging countries to understand how they are seen by consumers around the world.

Thus, one point meriting the interest of researchers relates to the identification of factors that generate trust in firms from emerging markets (Kabadayi \& Lerman, 2011). Among the factors that generate trust, reputation occupies a prominent position (Doney \& Cannon, 1997; Kang \& Yang, 2010). In terms of the theory of signals, reputation is more useful as a generator of trust when firms and their products are not well known, as happens with foreign firms and products (Nijssen, Singh, Sirdeshmukh \& Holzmuelle, 2003). Under such circumstances, reputation of firms from a particular country becomes an evaluation criterion for available offer and a cornerstone in the construction of a trust-based relationship (Michaelis, Woisetschläger, Backhaus \& Ahlert, 2008; Nijssen \& Herk, 2009). Thus, the first hypothesis proposes that: 
H1. The reputation of firms from an emerging country positively influences consumer trust in firms from that COO.

When relevant information is limited, as at the start of a relationship or in the purchase of foreign products, judgments regarding trustworthiness can start to form on the basis of the consumer's individual emotional mindset. Dunn \& Schweitzer (2005) affirm that, in general, positive emotions (happiness or gratitude) increase trust, whereas negative emotions (anger, sadness or guilt) reduce it. Negative emotions play an important role in the deterioration of trust, although on many occasions consumers are not aware of how much their emotional states of mind can impact their judgments and behaviour (Kiefer, 2005).

Animosity towards a country encompasses negative feelings of anger, hostility, antipathy or rejection with regard to people, customs, ideas or products from that country and, as such, can influence judgments on the reliability and integrity of its firms. Despite emotions playing an essential role in the generation, conservation or deterioration of trust, authors have found in the literature review no empirical evidence on the relationship between animosity and trust. Dunn and Schweitzer (2005) and Kiefer (2005) report evidence of the negative influence of other negative emotions on trust. By analogy with those other negative feelings, we expect that animosity towards a country may reduce trust in firms from that country. Thus:

H2. Consumer animosity towards an emerging country negatively influences consumer trust in firms from that $\mathrm{COO}$.

\subsection{The Decision to Purchase Foreign Products}

The variables included in this study are therefore expected to explain, at least partially, consumer purchase intention in relation to foreign products. In consumer-firm relations, trust generates a set of beliefs and positive expectations about the future behaviour of the parties (Ganesan, 1994; Morgan \& Hunt, 1994; Doney \& Cannon, 1997; Singh \& Sirdeshmukh, 2000). In the framework of the commitment-confidence theory, and in particular the relationship marketing approach, trust plays a key role in developing purchase intention because consumers prefer to interact with firms whose social norms and cultural rules of fair play govern their behaviour (Singh \& Sirdeshmukh, 2000). In particular, trust occupies a central position in establishing relations in which consumers and firms have different social and cultural origins (Shaffer \& O'Hara, 1995; Dahlstrom \& Nygaard, 1995). We therefore propose that:

H3. Consumer trust in firms from an emerging country positively influences consumer intention to purchase products from that $\mathrm{COO}$.

With regard to animosity, the literature shows that hostility and antipathy towards a particular foreign country has a direct and negative effect on the intention to purchase its products (Klein et al., 1998; Ettenson and Klein, 2005; Hoffmann et al., 2011), regardless of the valuation those products deserve in terms of quality and price. Although triggered by a specific event, animosity is a generalized feeling of rejection or enmity towards a country that materializes as a rejection of everything considered to represent that country, including its firms and products. In consequence,

H4. Consumer animosity towards an emerging country negatively influences consumer intention to purchase products from that $\mathrm{COO}$.

\section{Methodology}

\subsection{Scope of the Study}

$80 \%$ of the world's consumers live in emerging markets and transitional economies, despite the research about consumer from emerging markets results insufficient (Steenkamp \& Burgess, 2002). Understanding emerging consumer market behavior has thus become a topic with theoretical and practical implications for marketing knowledge. In response to this, the present study deals with the $\mathrm{COO}$ affective and cognitive effects of automobiles from an emerging country (Korea) on consumers from a transitional economy (Mexico). Mexico and Korea are two of the eight countries with at least a 1\% share of global GDP (O'Neill, Stupnytska \& Wrisdale, 2011).

As regards the product category chosen for the empirical test, automobile is a durable consumer good that is particularly important in the economic and social life of developing countries. In the case of Mexico, the number of newly registered vehicles has doubled in the last ten years (National Institute of Geography and Statistical, INEGI, 2000-2010) and the automobile sector accounts for 3.2\% of Mexican Gross Domestic Product (INEGI, 2010). Due to the current international economic crisis, the purchase of automobiles has slowed down over the last two years; the average rate of new vehicle registrations in Mexico has considerably falling (21\%). Despite 
the crisis in the automobile sector, it is interesting to note that registration of new Asian vehicles has increased 11\% in Mexico (Mexican Automotive Industry Association, 2010). Specifically, Asian vehicles with the greatest share in the Mexican market are Japanese (specifically, Nissan, Honda, Toyota, Mazda and Mitsubishi which account for $34.9 \%$ of all automobiles sold, including production and imports, in Mexico over the last year). However, other vehicles (i.e., Hyundai, Daewoo and Chery) from emerging Asian countries such as China and Korea are slowly entering the Mexican market through well-established automotive companies such as GM, Chrysler and Ford (Secretaría de Economía, 2010).

From the perspective of the individual consumer, purchasing an automobile is an important decision that implies risk and generally requires a considerable financial outlay. Hence, consumers are ready to make a greater effort to search for and evaluate information before purchasing an automobile than they might otherwise do for other products. It is also a difficult decision due to the technological and functional complexity of the product and given the existence of informational asymmetry that prevents the consumer from accessing all the necessary information required to evaluate all the purchase options on the market. Finally, the automobile is a product that has a symbolic meaning or status, which is why consumers are particularly sensitive to the product's COO (Harridge-March, 2006).

\subsection{Sample and Measurement Scales}

Having defined the scope of the empirical study, we employ questionnaires to gather the information, with a response rate of $78.3 \%$ [274 valid questionnaires from a total of 350 attempts and a sampling error of $\pm 6.90 \%$ $(\mathrm{p}=\mathrm{q}=0.5)]$. We carry out a survey and interview individuals that responded affirmatively to the filter question of being vehicle users and owners and voluntarily agreed to answer the questionnaire at different points in the streets of the three largest important cities in Mexico. Vehicle users and owners generally possess sufficient knowledge of automobiles and their countries of origin, an aspect that is essential for the interviewee answering the questionnaire to be able to respond satisfactorily to questions on purchase behaviour. A spontaneous memory question put to interviewees before correctly mentioning at least two Korean brands, results confirming that the majority of interviewees correctly distinguish Korean automobile brands. Nevertheless, before asking any further questions we remind consumers of all Korean automobile brands. By doing so, we ensured that consumers responded to the questionnaire bearing in mind Korean automotive firms and not others that might mistakenly believe to be Korean.

The demographic and socio-economic profile of the sample consisted mainly of males (59.9\%) between 26 and 45 years of age (53.6\%). 35.6\% has completed secondary education studies, vocational studies or has further education qualifications, whilst $44.5 \%$ has higher education qualifications. $40.1 \%$ were self-employed, and $44.8 \%$ of those interviewed fall into a monthly income bracket of between $€ 1001$ and $€ 1500$.

We adopt items from previous literature to measure each variable. In this study, we principally use the scales of Doney and Cannon (1997) and Kang and Yang (2011) to measure the reputation of firms from the COO, and the scales of Ganesan (1994) and Doney and Cannon (1997) to measure trust. We adapt the indicators of animosity from the studies of Klein et al. (1998); Ettenson and Klein (2005) and Hoffman et al. (2011). Finally, we employ the scales used by Grewal, Gotlieb and Marmorstein. (1998) and Ettenson and Klein (2005) to measure the consumer purchase intention scale. This study makes use of five-point Likert type scales and we conduct a pre-test with 30 individuals to check the questionnaire to be used, pinpointing errors of understanding in the questions.

\subsection{Analysis and Results}

The preliminary analysis confirms the normality of the data, no multicollinearity problems and the unidimensionality of the measurement scales (Bagozzi \& Baumgartner, 1994). Afterwards, the confirmatory factorial analysis carried out using the LISREL programme sought to test the validity of the measurement model (Jöreskog \& Sörbom, 1993). The results serve to provide the final scales and determine the convergent and discriminant validity of the measurement model. The direct relation between each construct and its corresponding measurements proves significant to $95 \%$ in all cases $(t>1.96)$, but it is necessary to eliminate two items (V13 and V16) since they has a low $\mathrm{R}^{2}$. After that, the fit of the adjusted model is acceptable $(\chi 2=400.346$ $(\mathrm{p}=0.00)$; RMSEA=0.04; NFI=0.93; $\mathrm{CFI}=0.97$; IFI=0.97; GFI=0.89; $\mathrm{AIC}=484.03$; Saturated model $\mathrm{AIC}=600$; Independent model $\mathrm{AIC}=5826.62)$, the Cronbach's alpha, composite reliability and the variance extracted were above the acceptable values of 0.7, 0.6 and 0.5, respectively (Bagozzi \& Yi, 1988). With regard to discriminant validity, results show that the variance extracted value is at all times higher than the correlations of the square with other constructs (Bagozzi \& Yi, 1988). Having obtained an acceptable measurement model, the following 
step is to estimate the structural global model. Figure 1 shows the final estimated model and provides information on the coefficients and the values of the $t$ statistic (in brackets).

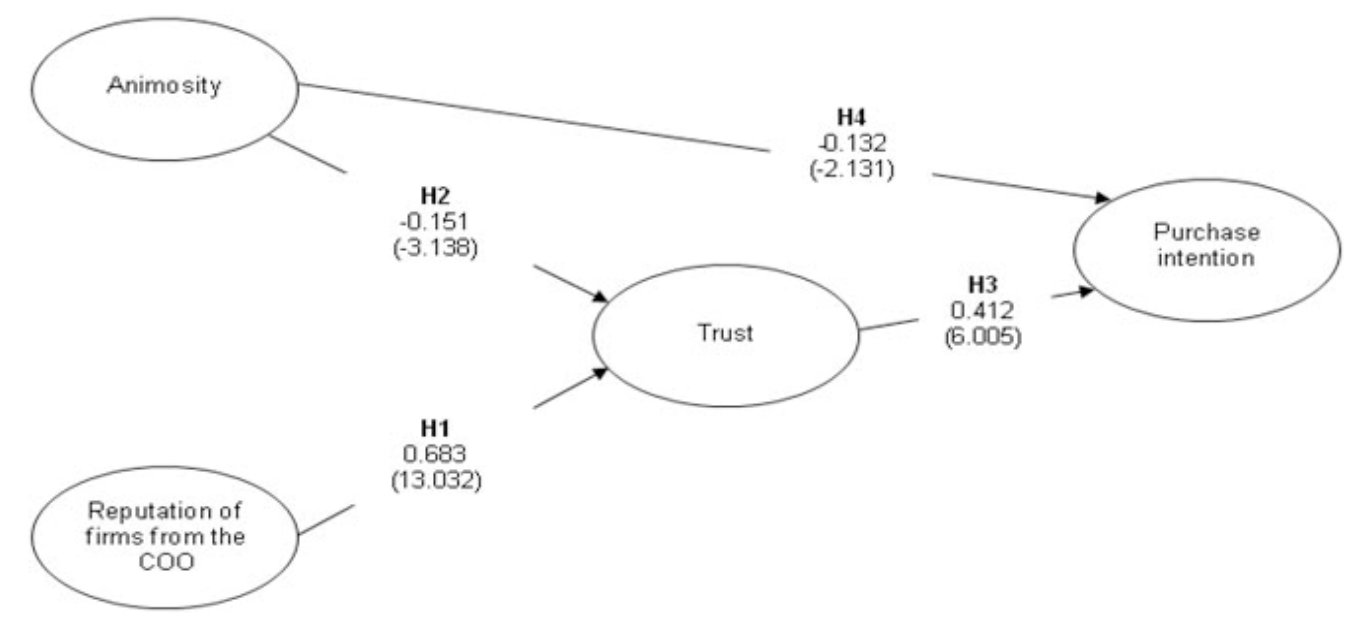

Goodness of fit index: $\chi 2=615.25 \quad(p=0.00) ;$ RMSEA $=0.06$, NFI $=0.92 ;$ CFI $=0.96 ; \quad$ IFI $=0.96 ; \quad G F I=0.87$; $\mathrm{AIC}=637.25$; Saturated model AIC $=688.10$; Independent model $\mathrm{AIC}=5820.16$.

Figure 1. Estimation results of the structural global model

As regards the antecedents of trust, the results show a significant and positive relationship between the reputation of COO firms and trust $(\lambda=0.683, \mathrm{p}<0.01)$ and, a negative effect of animosity on trust $(\lambda=-0.151, \mathrm{p}<0.01)$, meaning that we can accept the hypotheses H1 and H2. Finally, with regard to variables proposed as antecedents to purchase intention: our results confirm the positive effect of trust on purchase intention, therefore we do no reject the hypothesis $(\lambda=0.412, \mathrm{p}>0.01)$, and confirm the negative effect of animosity on purchase intention, thus we accept the hypothesis $\mathrm{H} 4(\lambda=-0.132, \mathrm{p}<0.01)$. The final section of this study describes the implications arising from or results in greater detail in the final section.

Additionally, we have tried to determine if trust mediates the relationship between reputation of firms of an emerging market and purchase intention. In order to test the mediation effect of trust, we develop and compare two structural equation models using LISREL. The first model is the proposed theoretical model (Figure 1) proposing an indirect relationship between reputation of firms from an emerging market and purchase intention. The second model depicts a scenario where reputation of firms from an emerging market directly influences purchase intention (Yen \& Gwinner, 2003). Our results confirm that trust has a mediating effect in the influence of reputation of firms from an emerging market on purchase intention: 1) The predictor variable (reputation) significantly influences the dependent variable (purchase intention) $(\lambda=0.431 ; \mathrm{t}=6.655)$. There is a significant relationship between the predictor variable (reputation) and the mediator variable (trust) $(\lambda=0.674 ; \mathrm{t}=12.733$ ), and 3) after controlling for the mediator variable (trust), the effect of the predictor variable (reputation) on the dependent one (purchase intention) decreases in strength $(\lambda=0.342 ; \mathrm{t}=3.384)$ (Baron $\&$ Kenny, 1986). Finally, Sobel test shows the significance of the mediation effect of trust on the association between reputation of firms from an emerging market and purchase intention (Sobel $z$-value $=5.45 ; p$-value $=0.000$ ) and it also indicates the existence of a mediation effect of trust.

\section{Conclusions}

The present work integrates various theoretical approaches and different components of $\mathrm{COO}$ effect (firm $\mathrm{COO}$ reputation and animosity). The results of this study show that animosity towards a country can reduce trust towards what comes out of that country, including its firms and products. As opposed to animosity, the business reputation of a foreign country contributes to increasing trust in its firms. In this sense, our results confirm the role of the reputation of firms from the product's $\mathrm{COO}$ as a quality sign, expressed in the capacity to transmit indirect information to the consumer that helps to dispel doubts and fears regarding the advisability of acquiring products from an emerging country, and to engender trust in firms from emerging countries. 
Moreover, said reputation is also an indirect determinant of the purchase of foreign products in emerging markets. Also, trust emerges as a stimulating factor in the purchase behaviour of products from emerging markets. These results prove extremely interesting because one problem related to new market economies -such as Korea- is the question of building trust in global markets. There is an association between institutionalized trust of a country and country elements that safeguard brands, firms' transactions, banking system and contracts. Specifically, Zucker (1986) suggest that there is closely relationship between institutional trust and COO. Trust in a country's legal system, laws and contracts are important issues that help consumers to trust in brands and products from that COO (Dahlstrom \& Nygaard, 1995). We can argue reform the findings that whenever institutional based trust does not exist (as is often the case in new market economies) consumers may base their purchase decisions on inter-personal based trust or heuristic cues, such as COO reputation. If the firm does not have a readily identifiable brand name, which is the case of firms from emerging economies (Kang \& Yang, 2010), reputation of firms associated to a COO plays an important role in solving the asymmetry information problem faced by the consumer when buying foreign products. While building institutional-based trust in international markets takes time due to macroeconomic conditions and social structure (Dahlstrom \& Nygaard, 1995), the reputation of firms from emerging countries works as a safeguard transaction element (Steenkamp \& Geyskens, 2006).

Our results suggest that, when evaluating the purchase decision process of a foreign product from an emerging country, consumers attach greater importance to the business reputation and reliability of the foreign product's COO. Moreover, reputation of firms from an emerging market has an indirect effect on purchase decision through trust. This empirical observation coincides with the findings of Michaelis et al. (2008), who hold that consumers facing an uncertain purchase situation (the case of value products from emerging countries) primarily draw on indicators that signal foreign product quality (such as the reputation of the $\mathrm{COO}$ firms) until when they start to trust a foreign firm. In line with the above argument, a foreign firm's reputation is the key deciding factor in consumer purchase decision in our study.

Finally, although with less of an impact than the indirect effect of reputation of firms from the $\mathrm{COO}$ and trust on purchase intention, animosity also emerges as a determinant in product purchase intention from the country. This occurs through two channels of influence. Firstly, an indirect channel may be seen through its trust-reducing effect. Secondly, animosity has a direct and negative effect on purchase intention. Consequently, consumers who feel animosity towards an emerging country are reluctant to purchase its products, even if they appreciate the prestige of its firms and trust its good intentions and capabilities.

\subsection{Implications of Interest for Business Management}

In the framework described, firms seeking to internationalize then need to find out how to overcome the hurdle of target market animosity, and to promote purchases in international markets.

When the problem is animosity towards a certain emerging country, firms can tackle it by increasing consumer knowledge, awareness and understanding of such countries can prompt consumers to accept products from emerging countries with more easily (Hannerz, 1990). As Ettenson and Klein (2005) suggest, foreign firms may first try to detach themselves from the country that causes animosity and link themselves to another that does not spark such a feeling. A second way of ridding themselves of the negative image that haunts them as manufacturers from a hostile country is for firms to highlight their international projection and global identity (Wang, 2005).

Having reviewed some of the possibilities available to foreign firms to protect themselves against the negative effects of consumer animosity, it is worth remembering that reputation is also the principal determinant of the trust placed in foreign firms, its capacity to generate trust (total positive effect) being much stronger than the capacity of animosity to reduce it (direct negative effect). Finally, reputation is a powerful determinant behind purchase intention, its indirect effect through trust on the final dependent variable being greater than the corresponding total negative effects of animosity. Firms from emerging countries are thus urged to place greater emphasis on strategies aimed at improving their country's international reputation, above all among their target markets. This will in no way curtail the damaging effects of potential consumer animosity but it will, however, more than counterbalance them.

A country's international reputation depends firstly on the overseas image of its population, its public and private institutions, its dominant values and the history of its behaviour. If, moreover, a country is able to build up and maintain over time a good overseas image, this will in good measure depend on how its firms behave and perform in the international arena. With good reason consumers remember countries for their best known firms, which often provide the most visible facet of a country's general behaviour. In this sense, if creating a strong 
country brand at a global level is in the interest of a country's government and public administration, the best way to achieve this is precisely by supporting firms that already have a positive international reputation and whose business behaviour reaches beyond national frontiers (Kang \& Yang, 2010). For emerging countries and whose country brand is not so well consolidated, promoting a group -however small- of internationalized firms is essential, particularly if it is in an innovative technological sector which can generate a knock-on effect for other firms and can create a protective umbrella for future business plans abroad through reputation and trust gained in international markets.

\subsection{Limitations of the Study and Future Lines of Research}

Our study presents some limitations that offer opportunities for future research. It is clear, that considering only one product, a single $\mathrm{COO}$ for the product, and a single country of sale for the case study analysis, restricts the possibilities of generalizing the study's findings. In order to overcome this limitation, future studies should project the model onto other products and services, others $\mathrm{COO}$ and markets of sale. In addition, the virtual lack of any national alternatives conditions the results of our analysis. Future studies should thus address products that comply with one basic condition, namely that both national and foreign brands should both compete in the country of sale.

Considering Korea as the product $\mathrm{COO}$ also entails some notable limitations. In the case of the Mexican market, Korea hardly appears to create a generalized feeling of animosity. Moreover, Korean firms in general, and Korean manufacturers in particular, do not enjoy a good reputation and a high level of acceptance in the Mexican market (it may be a result of the recently introduction of the Korean automobiles to the Mexican market). These circumstances suggest that future studies should compare consumer responses to products from two or more countries with differing international images and with a different degree of business reputation.

Also, we propose certain future avenues for furthering this research. The first possibility is to improve the specification of the model by introducing moderating (or interactive) relations among the variables considered. Secondly, it would be interesting to add potentially explanatory variables for consumer animosity. Finally, a third possibility is to explore in depth the mechanisms that developing countries could use to generate trust in their firms and thus to counteract the absence of strengthen institutional mechanisms (such as laws and codes of behaviour) that guarantee the normal development of transactions in the international market (Dahlstrom \& Nygaard, 1995; Steenkamp \& Geyskens, 2006).

\section{Acknowledge}

The authors thank the support of UASLP/PROMEP/103.5/11/6650, SNI/CONACYT: 53181 and UASLP-FAI: C12-FAI-03-08.08.

\section{References}

Amine, L. S., \& Chao, M. C. H. (2005). Managing country image to long-term advantage: The case of Taiwan and Acer. Place Branding, 1, 187-204. http://dx.doi.org/10.1057/palgrave.pb.5990020

Amine, L.S. (2008). Country-of-origin, animosity and consumer response: Marketing implications of anti-Americanism and Francophobia. International Business Review, 17, 402-422. http://dx.doi.org/10.1016/j.ibusrev.2008.02.013

Bagozzi, R. P., \& Baumgartner, H. (1994). The evaluation of structural equation models and hypothesis AM testing. In Principles of Marketing Research (pp. 86-419), Basil Blackwell.

Bagozzi, R.P., \& Yi, Y. (1988). On the evaluation of structural equation models. Journal of the Academy of Marketing Science, 16, 74-94. http://dx.doi.org/10.1007/BF02723327

Baron, R. M., \& Kenny, D. A. (1986). The moderator-mediator variable distinction in social psychological research. Conceptual, strategic, and statistical considerations. Journal of Personality \& Social Psychology, 51, 1173-1182. http://dx.doi.org/10.1037/0022-3514.51.6.1173

Bisquerra, R. (1989). Introduction to multivariant analysis. SPSS X, BMDP, LISREL, SPAD, 15. University promotion and publication I and II.

Boomsma, A., \& Hoogland, J. J. (2001). The robustness of LISREL modelling. In R. Cudeck, S. du Toit, and D. Sörbom (Eds.), Structural equation models: Present and future. Chicago: Scientific Software International.

Dahlstrom, R., \& Nygaard, A. (1995). An Exploratory Investigation of Interpersonal Trust in New and Mature Market Economies. Journal of Retailing, 71, 339-361. http://dx.doi.org/10.1016/0022-4359(95)90018-7 
Doney, P.M., \& Cannon, J.P. (1997). An examination of the nature of trust in buyer-seller relationships. Journal of Marketing, 61, 35-51. http://dx.doi.org/10.2307/1251829

Dunn, J.R., \& Schweitzer, M.E. (2005). Feeling and Believing. The Influence of Emotion on Trust. Journal of Personality and Social Psychology, 88, 736-748. http://dx.doi.org/10.1037/0022-3514.88.5.736

Ettenson, R., \& Klein J.G. (2005). The fallout from French nuclear testing in the South Pacific. International Marketing Review, 22, 199-224. http://dx.doi.org/10.1108/02651330510593278

Fombrun, C., \& Shanley, M. (1990). What's in a Name? Reputation Building and Corporate Strategy. Academy of Management Journal, 33, 233-258. http://dx.doi.org/10.2307/256324

Ganesan, S. (1994). Determinants of long-term orientation in buyer-seller relationships. Journal of Marketing, 58, 1-19. http://dx.doi.org/10.2307/1252265

Grewal, D., Gotlieb, J., \& Marmorstein, H. (1994). The moderating effects of message framing and source credibility on the price-perceived risk relationship. Journal of Consumer Research, 21, 145-153. http://dx.doi.org/10.1086/209388

Hamzaoui-Essoussi, L., Merunka, D., \& Bartikowski, B. (2011). Brand origin and country of manufacture influences on brand equity and the moderating role of brand typicality. Journal of Business Research, 64, 973-978. http://dx.doi.org/10.1016/j.jbusres.2010.11.020

Hannerz, U. (1990). Cosmopolitans and locals in world culture. Theory, Culture and Society, 7, 237-251. http://dx.doi.org/10.1177/026327690007002014

Harridge-March, S. (2006). Can the building of trust overcome consumer perceived risk online?. Marketing Intelligence and Planning, 24, 746-761. http://dx.doi.org/10.1108/02634500610711897

Hoffmann, S., Mai, R., \& Smirnova, M. (2011). Development and Validation of a Cross-Nationally Stable Sc ale of Consumer Animosity. Journal of Marketing Theory and Practice, 19, 235-251. http://dx.doi.org/10.2753/MTP1069-6679190208

Jöreskog, K. G., \& Sörbom, D. (1993). LISREL 8. Structural equation modeling with the SIMPLIS command language. Chicago, IL. Scientific Software International.

Kabadayi, S., \& Lerman, D. (2011). Made in China but sold at FAO Schwarz. country-of-origin effect and $\begin{array}{llll}\text { trusting } \quad \text { beliefs. International } & \text { Marketing }\end{array}$ http://dx.doi.org/10.1108/02651331111107125

Kalwani, M.U., \& Narayandas, N. (1995). Long-term manufacturer-supplier relationships. Do they pay Off for Supplier Firms?. Journal of Marketing, 59(1), 1-16. http://dx.doi.org/10.2307/1252010

Kang, M., \& Yang, S.U. (2010). Comparing effects of country reputation and the overall corporate reputations of a country on international consumers' product attitudes and purchase intentions. Corporate Reputation Review, 13, 52-63. http://dx.doi.org/10.1057/crr.2010.1

Kiefer, T. (2005). Feeling bad. antecedents and consequences of negative emotions in ongoing change. Journal of Organizational Behaviour, 26, 875-897. http://dx.doi.org/10.1002/job.339

Klein, J.G., Ettenson, R., \& Morris, M. (1998). The animosity model of foreign product purchase. an empirical test in the People's Republic of China. Journal of Marketing, 62, 89-100. http://dx.doi.org/10.2307/1251805

Maher, A.A., \& Carter, L.L. (2011). The affective and cognitive components of country image. Perceptions of American products in Kuwait. International Marketing Review, 28, 559-580. http://dx.doi.org/10.1108/02651331111181411

Mexican Automotive Industry Association (2010). Statistics. Retrieved from http://www.amia.com.mx

Michaelis, M., Woisetschläger, D.M., Backhaus, C., \& Ahlert., D. (2008). The effects of country-of-origin and corporate reputation on initial trust. An experimental evaluation of the perception of Polish consumers. International Marketing Review, 25, 404-422. http://dx.doi.org/10.1108/02651330810887468

Morgan, R.M., \& Hunt, S.D. (1994). The commitment-trust theory of relationship marketing. Journal of Marketing, 58, 20-38. http://dx.doi.org/10.2307/1252308

National Institute of Geography and Statistical. (2000-2010). Statistics of automobiles registrations. Retrieved from http://www.inegi.org.mx 
Nijssen, E., Singh, J., Sirdeshmukh, D., \& Holzmueller, H. (2003). Investigating Industry Context Effects in Consumer-Firm Relationships. Preliminary Results from a Dispositional Approach. Journal of the Academy of Marketing Science, 31, 46-60. http://dx.doi.org/10.1177/0092070302238604

Nijssen, E.J., \& Douglas S.P. (2004). Examining the animosity model in a country with a high level of foreign trade. International Journal of Research in Marketing, 21, 23-38. http://dx.doi.org/10.1016/j.ijresmar.2003.05.001

Nijssen, E.J., \& Herk, H. (2009). Conjoining International Marketing and Relationship Marketing. Exploring Consumers' Cross-Border Service Relationships. Journal of International Marketing, 17, 91-115. http://dx.doi.org/10.1509/jimk.17.1.91

O’Neill, J., Stupnytska, A., \& Wrisdale, J. (2011). It is Time to Re-define Emerging Markets. Strategy Series, ed. Goldman Sachs Asset Management, 1-12.

Parameswaran, R., \& Pisharodi, R M. (1994). Facets of country of origin image: An empirical assessment. Journal of Advertising, 23, 43-56.

Roth, K.P., \& Diamantopoulos, A. (2009). Advancing the country image construct. Journal of Business Research, 62, 726-740. http://dx.doi.org/10.1016/j.jbusres.2008.05.014

Secretaría de Economía (2010). Estadísticas de Comercio Internacional. Retrieved from http.//www.economia.gob.mx/swb/es/economia/p_Estadisticas_de_Comercio_Internacional

Shaffer, T.R., \& O'Hara, B.S. (1995). The effects of country-of-origin on trust and ethical perceptions of legal services. The Service Industries Journal, 15, 162-185. http://dx.doi.org/10.1080/02642069500000019

Sharma, P. (2011). Country-of-origin effects in developed and emerging markets. Exploring the contrasting roles of materialism and value consciousness. Journal of International Business Studies, 42, 285-306. http://dx.doi.org/10.1057/jibs.2010.16

Shi, Z., Wen, L., \& Fan, L. (2012). How Chinese Face Perception Influences Consumer's Implicit and Explicit Attitude towards Brand Country of Origin. International Journal of Business and Management, 7, 123-139. http://dx.doi.org/10.5539/ijbm.v7n5p123

Shimp, T. A., \& Sharma, S. (1987). Consumer Ethnocentrism: Construction and Validation of the CETSCALE. Journal of Marketing Research, 24, 280-289.

Singh, J., \& Sirdeshmukh, D. (2000). Agency and Trust Mechanisms in Consumer Satisfaction and Loyalty Judgments. Journal of the Academy of Marketing Science, 28, 150-167. http://dx.doi.org/10.1177/0092070300281014

Steenkamp, J.B., \& Burgess, S. (2002). Optimum stimulation level and exploratory consumer behaviour in an emerging consumer market. International Journal of Research in Marketing, 19, 131-150. http://dx.doi.org/10.1016/S0167-8116(02)00063-0

Steenkamp, J.-B.E.M., \& Geyskens, E. (2006). How country characteristics affect the perceived value of web sites. American Marketing Association, 70, 136-150.

Wang, J. (2005). Consumer nationalism and corporate reputation management in the global era. Corporate Communications. An International Journal, 10, 223-239.

Yen, R. H. J., \& K. Gwinner, P. (2003). Internet retail customer loyalty. the mediating role of relational benefits. International Journal of Service Industry Management, 14, 483-500. http://dx.doi.org/10.1108/09564230310500183

Zucker, L. G. (1986). Production of Trust. Institutional Sources of Economic Structure, 1840-1920. Research in Organizational Behaviour, 8, 53-111. 